\title{
PREPARASI SENYAWA ANTI KANKER APIGENIN BERTANDA RADIOIODIUM-131 UNTUK STUDI BIOAKTIVITAS
}

\author{
Teguh Hafiz Ambar Wibawa ${ }^{1^{*}}$, Eva Maria Widyasari $1^{1^{*}}$, Iswahyudi ${ }^{1 * *}$, Ade Suherman ${ }^{1 * *}$, \\ Maula Eka Sriyani ${ }^{1^{* *}}$, Ahmad Kurniawan ${ }^{1^{* \star}}$, Danni Ramdhani ${ }^{2^{* \star}}$ \\ ${ }_{1}$ Pusat Sains dan Teknologi Nuklir Terapan - Badan Tenaga Nuklir Nasional \\ Jl. Tamansari No. 71 Bandung, Indonesia \\ ${ }^{2}$ Fakultas Farmasi, Universitas Padjadjaran \\ Jl. Raya Bandung - Sumedang, Km. 21 Jatinangor \\ *kontributor utama, ${ }^{* *}$ kontributor anggota \\ email: teguh.haw@gmail.com
}

Diterima: 24-04-2020

Diterima dalam bentuk revisi: 16-07-2020

Disetujui: 20-07-2020

\begin{abstract}
ABSTRAK
PREPARASI SENYAWA ANTI KANKER APIGENIN BERTANDA RADIOIODIUM-131 UNTUK STUDI BIOAKTIVITAS. Apigenin merupakan senyawa flavonoid yang mempunyai potensi sebagai senyawa anti kanker, anti oksidan, dan anti inflamasi dengan toksisitas intrinsik yang rendah. Untuk mengetahui bioaktivitas apigenin, dapat dilakukan radioiodinasi kemudian dilanjutkan dengan studi praklinis menggunakan hewan uji. Pada penelitian ini dilakukan preparasi apigenin bertanda radioiodium-131 menggunakan metode kloramin-T dan optimasi berbagai parameter serta kondisi penandaan. Hasil optimasi diperoleh formula dan kondisi penandaan yaitu $1 \mathrm{mg}$ apigenin, $250 \mu \mathrm{g}$ kloramin- $\mathrm{T}$, dan $100 \mu \mathrm{g}$ natrium metabisulfit, dengan $\mathrm{pH}$ penandaan 7 dan jumlah radioiodium-131 $10 \mu \mathrm{L}(10 \mu \mathrm{Ci})$. Proses penandaan senyawa ${ }^{131} \mathrm{I}-$ Apigenin dilakukan melalui reaksi substitusi elektrofilik selama 20 menit pada suhu kamar (20$22^{\circ} \mathrm{C}$ ). Dari hasil pengujian menggunakan metode kromatografi kertas menggunakan fasa diam Whatman 1 dan fasa gerak amonium asetat $0,02 \mathrm{M}, \mathrm{pH} 6$, diperoleh kemurnian radiokimia sebesar $96,53 \pm 1,87 \%$. Hasil tersebut menunjukkan bahwa ${ }^{131}$ I-Apigenin dapat digunakan untuk studi selanjutnya, yaitu studi fisikokimia dan studi praklinis, sehingga dapat diperoleh karakteristik bioaktivitas dan efektivitasnya sebagai senyawa anti kanker berbasis bahan alam.
\end{abstract}

Kata kunci: Apigenin, Radioiodium-131, Senyawa Bertanda, Bahan Alam

\section{ABSTRACT}

PREPARATION OF RADIOIODINE-131 LABELED APIGENIN ANTI CANCER COMPOUND FOR BIOACTIVITY STUDY. Apigenin is a flavonoid derivative that has potential as a candidate of anti-cancer, anti-oxidant, and anti-inflammatory with low intrinsic toxicity. To determine the bioactivity of apigenin can be carried out by the radioiodination method and continue with a preclinical study using test animals. This research was conducted to prepared a ${ }^{131}$ I-Apigenin using the chloramine-T method and optimizing the parameters of radiolabeling. In this study, ${ }^{131} \mathrm{I}$-Apigenin was prepared with the formulation of $1 \mathrm{mg}$ apigenin, $250 \mu \mathrm{g}$ chloramine$\mathrm{T}$, and $100 \mu \mathrm{g}$ sodium metabisulfite in $\mathrm{pH} 7$ with an addition $10 \mu \mathrm{L}(10 \mu \mathrm{Ci})$ of radioiodine-131. The electrophilic substitution reaction was quite rapid within 20 minutes at room temperature (20$\left.22{ }^{\circ} \mathrm{C}\right)$. The radiochemical purity was confirmed by thin-layer chromatography using Whatman 1 as static phase and ammonium acetate $0,02 \mathrm{M}, \mathrm{pH} 6$ as mobile phase, the radiochemical purity was obtained $96,53 \pm 1,87 \%$. The result would make ${ }^{131}$ I-Apigenin continue for physicochemical 
and preclinical study to discover its bioactivity and effectiveness as an anti-cancer natural compound.

Key words: Apigenin, Radioiodine-131, Labeled Compound, Natural Compound

\section{PENDAHULUAN}

Kanker merupakan salah satu penyebab kematian di dunia. Pada tahun 2018 terdapat 18,1 juta kasus baru dan 9,6 juta kematian akibat kanker. Risiko kumulatif kasus kanker menunjukkan 1 dari 8 pria dan 1 dari 10 wanita dapat terkena kanker (1). Pengobatan kanker umumnya menggunakan senyawa dengan target sel-sel yang membelah dengan cepat. Namun, pendekatan ini memiliki efek samping negatif karena sel-sel yang membelah cepat seperti folikel rambut dan sel epitel dalam sistem pencernaan juga terpengaruh (2). Karena itu, dalam beberapa tahun terakhir banyak penelitian berfokus pada pengembangan terapi kanker yang efektif namun memiliki efek samping pada sel normal yang rendah. Dalam hal ini, senyawa bahan alam terbukti menjadi kandidat yang cocok untuk terapi kanker (3).

Salah satu senyawa bahan alam yang berpotensi menjadi anti kanker yaitu senyawa apigenin. Senyawa apigenin merupakan senyawa turunan flavonoid yang berlimpah di alam. Apigenin mempunyai rumus kimia $\mathrm{C}_{15} \mathrm{H}_{10} \mathrm{O}_{5}$ dengan berat molekul $270,24 \mathrm{~g} / \mathrm{mol}$ (4). Apigenin terdapat dalam jumlah yang besar pada berbagai tumbuhan dan buah-buahan seperti seledri, bawang, bunga kamomil, jeruk, dan daun teh (3-6). Apigenin mempunyai sifat sebagai senyawa kemopreventif kanker melawan berbagai tipe kanker (7-9). Hasil penelitian secara in vivo maupun in vitro menunjukkan bahwa apigenin mempunyai efek yang luar biasa terhadap sel kanker paru-paru (6), kanker ovarium (8), kanker payudara dan kanker kolon (10) dengan toksisitas intrinsik yang rendah (11). Selain itu, apigenin mempunyai aktivitas sebagai antioksidan $(12,13)$ dan anti inflamasi $(14,15)$. Hasil studi menunjukkan apigenin dapat menghambat proliferasi sel kanker yang diikuti dengan peningkatan spesies oksigen reaktif (ROS) (4). Untuk mengetahui bioaktivitas apigenin, dapat dilakukan radioiodinasi dan dilanjutkan dengan studi praklinis menggunakan hewan uji (16). Pada penelitian ini dilakukan preparasi apigenin bertanda radioiodium-131 menggunakan metode kloramin-T karena telah banyak digunakan, relatif simpel, murah, dengan hasil kemurnian radiokimia yang cukup memuaskan $(17,18)$ serta optimasi berbagai parameter dan kondisi penandaan. Sehingga dapat diperoleh senyawa apigenin bertanda radioiodium-131 yang dapat digunakan untuk studi bioaktivitas.

\section{METODOLOGI}

\section{Bahan dan Peralatan}

Bahan-bahan yang digunakan antara lain: apigenin (Sigma Aldrich), kloramin-T hidrat (Sigma Aldrich), $\mathrm{Na}^{131}$ I (PSTNTBATAN), dimetil sulfonamida (DMSO) (E. Merck), buffer asetat (E. Merck), kertas kromatografi Whatman 1 (Whatman), kertas selulosa asetat (E. Merck), amonium asetat (E. Merck), natrium metabisulfit (E. Merck), natrium hidroksida (E. Merck), asam klorida 
(E. Merck), kertas pH Universal (E. Merck), mikrotube (GenFollower), dan akuabides steril (IKA Pharma). Peralatan yang digunakan antara lain: vortex mixer (Biotech), alat elektroforesis (Gellman), oven (Memmert), radio-TLC scanner (Bioscan), pencacah gamma saluran tunggal (Ortec), dose calibrator (Victoreen), dan alat suntik (Terumo).

\section{Radioiodinasi Apigenin}

Radioiodinasi apigenin dilakukan dengan menggunakan metode kloramin-T. Agar diperoleh kemurnian radiokimia yang tinggi, dilakukan variasi beberapa parameter dan kondisi penandaan, meliputi jumlah apigenin, jumlah kloramin-T, jumlah natrium metabisulfit, jumlah radioiodium-131, $\mathrm{pH}$ larutan, dan waktu reaksi.

\section{Pembuatan Larutan Apigenin}

Apigenin ditimbang sebanyak $5 \mathrm{mg}$, kemudian dimasukkan ke dalam mikrotube ukuran $2 \mathrm{~mL}$, setelah itu ditambahkan $1 \mathrm{~mL}$ DMSO, larutan diaduk menggunakan vortex mixer hingga apigenin larut sempurna.

\section{Pembuatan Larutan Kloramin-T}

Kloramin-T ditimbang sebanyak $5 \mathrm{mg}$, kemudian dimasukkan ke dalam mikrotube ukuran $2 \mathrm{~mL}$, setelah itu ditambahkan $1 \mathrm{~mL}$ buffer asetat $0,2 \mathrm{M}, \mathrm{pH} 7$, larutan diaduk menggunakan vortex mixer hingga kloraminT larut sempurna.

\section{Pembuatan Larutan Natrium Metabisulfit}

Natrium metabisulfit ditimbang sebanyak $10 \mathrm{mg}$, kemudian dimasukkan ke dalam mikrotube ukuran $2 \mathrm{~mL}$, setelah itu ditambahkan $1 \mathrm{~mL}$ buffer asetat 0,2 M, pH 7, larutan diaduk menggunakan vortex mixer hingga natrium metabisulfit larut sempurna.

\section{Preparasi Apigenin Bertanda \\ Radioiodium-131}

Secara umum, radioiodinasi dilakukan dengan mereaksikan larutan apigenin, larutan kloramin- $\mathrm{T}$, dan larutan $\mathrm{Na}^{131}$ I pada waktu dan suhu tertentu, kemudian reaksi dihentikan dengan cara menambahkan larutan natrium metabisulfit. Persentase kemurnian radiokimia ${ }^{131}$ I-Apigenin ditentukan dengan menggunakan metode kromatografi kertas yang dilanjutkan dengan pencacahan radioaktivitas menggunakan alat radio $T L C$-scanner. Untuk memperoleh kemurnian radiokimia yang optimal, dilakukan optimasi terhadap jumlah bahan dan kondisi penandaan.

\section{Penentuan Persentase Kemurnian Radiokimia dengan Metode Kromatografi Kertas \\ Kertas kromatografi Whatman 1} dengan ukuran $1 \mathrm{~cm} \times 10 \mathrm{~cm}$ ditandai setiap $\mathrm{cm}$ dan diberi nomor dari -1 sampai 10 dengan menggunakan pensil. Larutan sampel ${ }^{131}$ I-Apigenin ditotolkan pada titik nol, kemudian dielusi dengan fasa gerak amonium asetat $0,02 \mathrm{M}, \mathrm{pH} 6$. Setelah dielusi, kertas kromatografi dikeringkan dan dicacah dengan menggunakan radio-TLC scanner. Prosedur yang sama dilakukan terhadap blanko (larutan $\left.\mathrm{Na}^{131} \mathrm{I}\right)$ (19). 


\section{Penentuan Persentase Kemurnian}

Radiokimia dengan Metode Elektroforesis

Kertas elektroforesis selulosa asetat ditandai dan diberi nomor -18 hingga +18 dengan menggunakan pensil. Kemudian sampel ${ }^{131}$ I-Apigenin ditotolkan pada titik 0 . Eluen yang digunakan yaitu larutan buffer asetat $\mathrm{pH} 7,5$. Elektroforesis dilakukan pada tegangan 350 Volt selama 1 jam. Setelah selesai, kertas elektroforesis dikeringkan, dipotong setiap $1 \mathrm{~cm}$, dan selanjutnya dicacah dengan menggunakan alat pencacah gamma saluran tunggal (20).

\section{Optimasi Jumlah Apigenin}

Dalam proses penandaan, salah satu parameter yang mempengaruhi kermurnian radiokimia yaitu jumlah apigenin. Untuk memperoleh jumlah apigenin optimum, maka perlu dilakukan variasi jumlah apigenin. Ke dalam 5 buah mikrotube ukuran $1 \mathrm{~mL}$ (A, B, C, D, dan E) dimasukkan larutan apigenin masing-masing sebanyak 100, 200, 300, 400, dan $500 \mu \mathrm{L}$. Kemudian dilakukan pengecekan $\mathrm{pH}$ menggunakan kertas $\mathrm{pH}$ universal, lalu $\mathrm{pH}$ diatur pada $\mathrm{pH} 7$ dengan cara menambahkan larutan asam klorida $0,01 \mathrm{~N}$. Ke dalam setiap mikrotube tersebut ditambahkan larutan $\mathrm{Na}^{131}$ I masing-masing sebanyak $10 \mu \mathrm{L}$. Selanjutnya pada setiap mikrotube ditambahkan larutan kloramin-T masing-masing sebanyak $10 \mu \mathrm{L}$. Setelah itu volume total dari kelima campuran disamakan dengan cara menambahkan larutan buffer asetat 0,2 M pH 7. Kelima mikrotube yg berisi campuran dikocok selama 5 menit, kemudian ditambahkan larutan natrium metabisulfit masing-masing sebanyak $10 \mu \mathrm{L}$. Selanjutnya dilakukan penentuan kemurnian radiokimia seperti ditunjukkan pada poin 2.7 .

\section{Optimasi Jumlah Kloramin-T}

Ke dalam 5 buah mikrotube ukuran 1 $\mathrm{mL}(\mathrm{A}, \mathrm{B}, \mathrm{C}, \mathrm{D}$, dan $\mathrm{E})$ dimasukkan larutan apigenin masing-masing sebanyak $200 \mu \mathrm{L}$. Kemudian dilakukan pengecekan $\mathrm{pH}$ menggunakan kertas $\mathrm{pH}$ universal, lalu $\mathrm{pH}$ diatur pada $\mathrm{pH} 7$ dengan cara menambahkan larutan asam klorida 0,01 N. Ke dalam setiap mikrotube tersebut ditambahkan larutan $\mathrm{Na}^{131}$ I masing-masing sebanyak $10 \mu \mathrm{L}$. Selanjutnya pada setiap mikrotube ditambahkan larutan kloramin-T dengan volume yang berbeda-beda, masing-masing sebanyak 10, 20, 30, 40, dan $50 \mu \mathrm{L}$. Setelah itu volume total dari kelima campuran disamakan dengan cara menambahkan larutan buffer asetat 0,2 M pH 7. Kelima mikrotube yg berisi campuran dikocok selama 5 menit, kemudian ditambahkan larutan natrium metabisulfit masing-masing sebanyak $10 \mu \mathrm{L}$. Selanjutnya dilakukan penentuan kemurnian radiokimia seperti ditunjukkan pada bagian 2.7.

\section{Optimasi pH Reaksi}

Ke dalam 5 buah mikrotube ukuran 1 $\mathrm{mL}(\mathrm{A}, \mathrm{B}, \mathrm{C}, \mathrm{D}$, dan $\mathrm{E})$ dimasukkan larutan apigenin masing-masing sebanyak $200 \mu \mathrm{L}$. Kemudian dilakukan pengecekan $\mathrm{pH}$ menggunakan kertas $\mathrm{pH}$ universal, lalu masing-masing campuran diatur pada $\mathrm{pH} 5$, 6 , 7, dan 8 dengan cara menambahkan larutan asam klorida $0,01 \mathrm{~N}$ atau natrium hidroksida $0,01 \mathrm{~N}$. Ke dalam setiap mikrotube 
tersebut ditambahkan larutan $\mathrm{Na}^{131}$ I masingmasing sebanyak $10 \mu \mathrm{L}$. Selanjutnya pada setiap mikrotube ditambahkan larutan kloramin-T masing-masing sebanyak $50 \mathrm{uL}$. Setelah itu volume total dari kelima campuran disamakan dengan cara menambahkan larutan buffer asetat $0,2 \mathrm{M} \mathrm{pH}$ 7. Kelima mikrotube yg berisi campuran dikocok selama 5 menit, kemudian ditambahkan larutan natrium metabisulfit masing-masing sebanyak $10 \mu \mathrm{L}$. Selanjutnya dilakukan penentuan kemurnian radiokimia seperti ditunjukkan pada bagian 2.7.

\section{Optimasi Jumlah Natrium lodida-131 $\left(\mathrm{Na}^{131} \mathrm{I}\right)$}

Ke dalam 3 buah mikrotube ukuran $\mathrm{mL}(\mathrm{A}, \mathrm{B}$, dan $\mathrm{C})$ dimasukkan larutan apigenin masing-masing sebanyak $200 \mu \mathrm{L}$. Kemudian dilakukan pengecekan $\mathrm{pH}$ menggunakan kertas $\mathrm{pH}$ universal, lalu masing-masing campuran diatur pada $\mathrm{pH} 7$ dengan cara menambahkan larutan asam klorida $0,01 \mathrm{~N}$ atau natrium hidroksida $0,01 \mathrm{~N}$. $\mathrm{Ke}$ dalam setiap mikrotube tersebut ditambahkan larutan $\mathrm{Na}^{131}$ I dengan volume yang berbeda, masing-masing sebanyak 10 , 50, dan $100 \mu \mathrm{L}$ (Akitivitas $\mathrm{Na}^{131} \mathrm{I}=1 \mathrm{mCi} / \mathrm{mL}$ ). Selanjutnya pada setiap mikrotube ditambahkan larutan kloramin-T masingmasing sebanyak $50 \mu \mathrm{L}$. Setelah itu volume total dari kelima campuran disamakan dengan cara menambahkan larutan buffer asetat $0,2 \mathrm{M} \mathrm{pH} 7$. Ketiga mikrotube yg berisi campuran dikocok selama 5 menit, kemudian ditambahkan larutan natrium metabisulfit masing-masing sebanyak $10 \mu \mathrm{L}$. Selanjutnya dilakukan penentuan kemurnian radiokimia seperti ditunjukkan pada bagian 2.7.

\section{Optimasi Waktu Reaksi Radioiodinasi}

Ke dalam 4 buah mikrotube ukuran 1 $\mathrm{mL}(\mathrm{A}, \mathrm{B}, \mathrm{C}$, dan D) dimasukkan larutan apigenin masing-masing sebanyak $200 \mu \mathrm{L}$. Kemudian dilakukan pengecekan $\mathrm{pH}$ menggunakan kertas $\mathrm{pH}$ universal, lalu masing-masing campuran diatur pada $\mathrm{pH} 7$ dengan cara menambahkan larutan asam klorida $0,01 \mathrm{~N}$ atau natrium hidroksida $0,01 \mathrm{~N}$. $\mathrm{Ke}$ dalam setiap mikrotube tersebut ditambahkan larutan $\mathrm{Na}^{131}$ I dengan volume yang sama, masing-masing sebanyak $10 \mu \mathrm{L}$. Selanjutnya pada setiap mikrotube ditambahkan larutan kloramin- $T$ masingmasing sebanyak $50 \mu \mathrm{L}$. Keempat mikrotube yg berisi campuran dikocok pada suhu ruang dengan waktu pengocokan yang berbeda, secara berturut-turut yaitu 5, 10, 20, dan 30 menit, kemudian ditambahkan larutan natrium metabisulfit masing-masing sebanyak $10 \mu \mathrm{L}$. Selanjutnya dilakukan penentuan kemurnian radiokimia seperti ditunjukkan pada bagian 2.7.

\section{HASIL DAN PEMBAHASAN}

Sintesis ${ }^{131}$ I-Apigenin dilakukan dengan menggunakan metode kloramin-T. Metode ini telah banyak digunakan, relatif simpel, murah, serta memberikan hasil yang memuaskan, tidak berbeda jauh dengan metode lodogen. Metode iodogen merupakan salah satu metode penandaan dengan radioiodium-131 yang menggunakan iodogen

(1,3,4,6-tetrachloro-3a,6a- 
difenilglukoluril) sebagai senyawa oksidatif $(17,18)$.

Apigenin dilarutkan dalam pelarut DMSO, karena pelarut aprotik ini dapat melarutkan apigenin dengan baik dibandingkan dengan air, $\mathrm{NaOH}$ maupun $\mathrm{KOH}$, sehingga larutan apigenin lebih stabil (14). Agar diperoleh kemurnian radiokimia yang tinggi, perlu dilakukan optimasi pada beberapa parameter penandaan, meliputi jumlah apigenin, jumlah kloramin-T, jumlah natrium metabisulfit, jumlah radioiodium-131, $\mathrm{pH}$ dan waktu reaksi.

Radioiodinasi senyawa apigenin pada penelitian ini menggunakan metode kloramin-T. Kloramin-T digunakan sebagai oksidator. Untuk mengoksidasi ion I' yang berasal dari $\mathrm{Na}^{131}$ I menjadi ion $\mathrm{I}^{+}$. Selanjutnya ion ' ' akan teroksidasi atau melepaskan elektron melalui reaksi oksidasi dengan kloramin- $T$ dan berubah menjadi $\mathrm{I}^{+}$dalam bentuk ICl (iodium monoklorida). Reaksi oksidasi ion I' ditunjukkan pada Gambar 1.

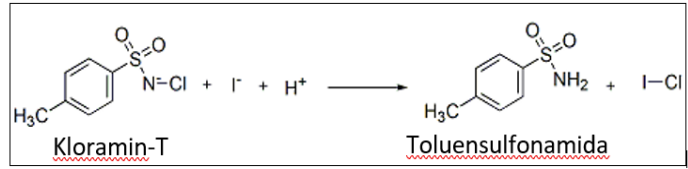

Gambar 1. Reaksi oksidasi ion I- menjadi ICI (iodium monoklorida) menggunakan kloramin-T (21)

Senyawa $\mathrm{ICl}$ yang terbentuk dari hasil oksidasi, selanjutnya mengalami ionisasi menjadi ion $\mathrm{I}^{+}$dan ion $\mathrm{Cl}^{-}$. Ion $\mathrm{I}^{+}$akan bereaksi dengan senyawa apigenin yang ditunjukkan pada Gambar 2.

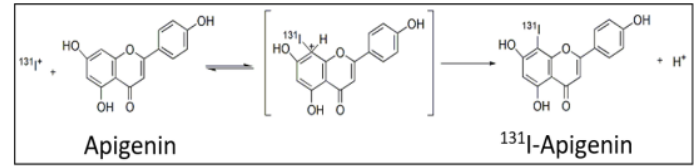

Gambar 2. Reaksi substitusi elektrofilik pada radioiodinasi senyawa apigenin (16)

Pada Gambar 2, reaksi yang terjadi merupakan reaksi substitusi elektrofilik. Pada tahap awal, terjadi protonasi atom karbon pada cincin aromatik membentuk karbokation. Selanjutnya karbokation distabilkan melalui delokalisasi elektron dan lepasnya ion $\mathrm{H}^{+}$, sehingga struktur molekul apigenin kembali stabil. Terdapat beberapa alternatif tempat masuknya ion $\mathrm{I}^{+}$, namun yang paling memungkinkan ion $\mathrm{I}^{+}$masuk pada posisi para, dikarenakan terdapat gugus hidroksi $(-\mathrm{OH})$ yang mempunyai sifat penarik elektron (electron withdrawing group) dan sekaligus sebagai gugus pengarah para. Hal ini sesuai dengan hasil penelitian sebelumnya dimana ion $\mathrm{I}^{+}$masuk posisi para cincin A dari senyawa apigenin (16).

Pengujian kemurnian radiokimia penandaan dilakukan dengan menggunakan metode kromatografi kertas. Hasil pengujian menunjukkan $\mathrm{Na}^{131}$ I mempunyai $\mathrm{Rf}=0,9-1$, sedangkan ${ }^{131} \mathrm{I}$-Apigenin mempunyai $\mathrm{Rf}=0$ 0,1, seperti ditunjukkan pada Gambar 3 . 


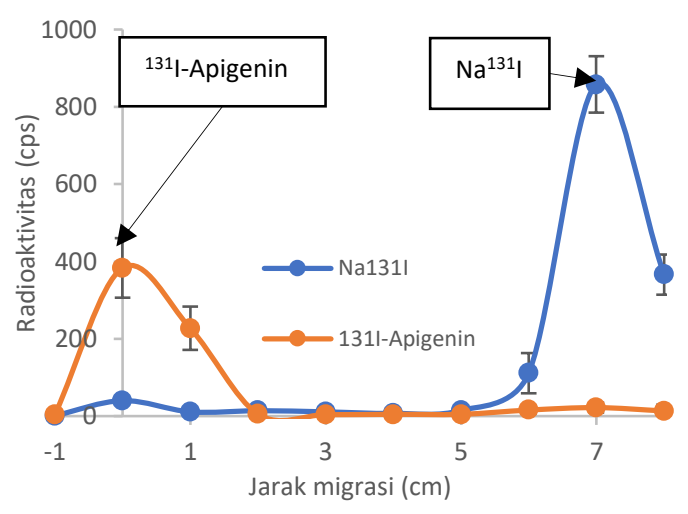

Gambar 3. Kromatogram $\mathrm{Na}^{131}$ I dan ${ }^{131}$ I-Apigenin menggunakan fasa diam Whatman 1 dan fasa gerak amonium asetat $0,02 \mathrm{M}, \mathrm{pH} 6$

\section{Optimasi Jumlah Apigenin}

Salah satu parameter yang menentukan pada preparasi ${ }^{131} \mathrm{I}$-Apigenin yaitu jumlah apigenin. Penentuan jumlah apigenin optimum dilakukan dengan cara memvariasikan jumlah apigenin mulai dari 100, 200, 300, 400, hingga $500 \mu \mathrm{L}$. Grafik hasil penentuan jumlah optimum apigenin ditunjukkan pada Gambar 4.

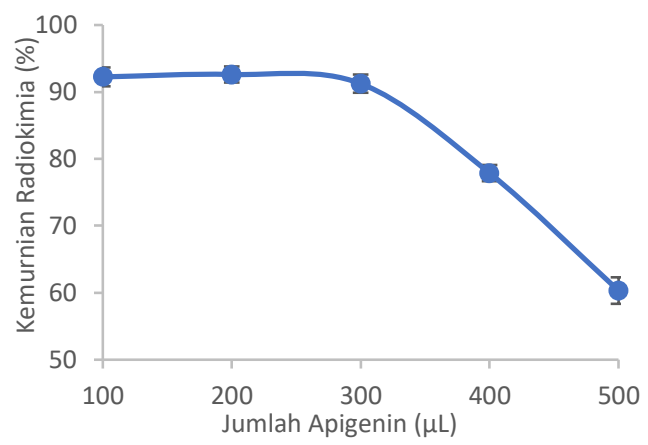

Gambar 4. Pengaruh jumlah apigenin terhadap kemurnian radiokimia hasil penandaan 131/Apigenin

Pada Gambar 4, diperoleh jumlah apigenin yang memberikan kemurnian radiokimia paling tinggi yaitu $200 \mu \mathrm{L}(1 \mathrm{mg})$. Selain itu terdapat kecenderungan semakin tinggi konsentrasi apigenin, semakin rendah kemurnian radiokimianya. Hal itu dapat disebabkan jumlah optimum telah tercapai pada jumlah apigenin $1 \mathrm{mg}$, yang berarti hampir seluruh molekul $\mathrm{Na}^{131}$ I telah bereaksi dengan molekul apigenin. Konsentrasi apigenin yang terlalu tinggi, akan banyak terdapat apigenin yang tidak tertandai radioiodium-131 dan dapat menghalangi reseptor (receptor blocking) pada saat studi in vivo (16).

\section{Optimasi Jumlah Kloramin-T}

Kloramin-T merupakan senyawa oksidator yang digunakan untuk mengoksidasi ion $\mathrm{I}^{-}$yang berasal dari ionisasi $\mathrm{Na}^{131} \mathrm{I}$. Kloramin-T mempunyai gugus elektrofilik aktif (atom klorin) dan gugus sulfonamida yang bersifat penarik elektron (electron withdrawing group) sehingga kloramin-T sangat mudah melepas ion $\mathrm{Cl}^{-}$dan mudah menangkap ion $\mathrm{H}^{+}$. Jumlah kloramin-T yang digunakan perlu dioptimasi agar diperoleh jumlah yang tepat. Penggunaan kloramin- $T$ yang berlebih dapat menyebabkan rusaknya senyawa apigenin karena kloramin-T mempunyai daya oksidasi yang kuat, sedangkan kekurangan kloramin$\mathrm{T}$ dapat menyebabkan tidak maksimalnya oksidasi ion $\mathrm{I}^{-}$(22). Ion $\mathrm{I}^{-}$yang tidak teroksidasi dapat menjadi pengotor pada proses penandaan. Hasil optimasi jumlah kloramin-T pada penandaan ${ }^{131}$ I-Apigenin ditunjukkan pada Gambar 5. 


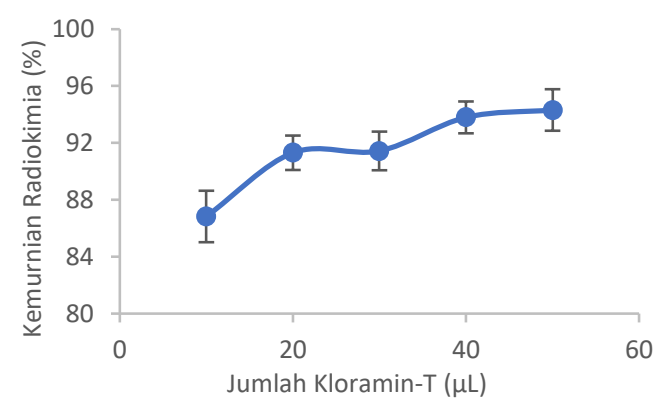

Gambar 5. Pengaruh jumlah kloramin-T terhadap kemurnian radiokimia hasil penandaan 131/Apigenin

Pada Gambar 5, jumlah kloramin-T yang memberikan kemurnian radiokimia ${ }^{131}$ IApigenin tertinggi yaitu $50 \mu \mathrm{L}(250 \mu \mathrm{g})$, yang berarti pada jumlah kloramin- $T$ tersebut cukup untuk bereaksi dengan molekul $\mathrm{Na}^{131}$ I. Grafik variasi jumlah kloramin-T yang cenderung menaik seiring penambahan jumlah kloramin-T, namun untuk menghindari rusaknya senyawa apigenin jumlah kloramin$T$ yang berlebih, maka jumlah kloramin- $T$ dibatasi hingga $250 \mu \mathrm{g}$. Pembatasan jumlah kloramin- $T$ dilakukan untuk menghindari kerusakan senyawa apigenin, hal ini dikarenakan kloramin-T merupakan senyawa yang sangat reaktif (22).

\section{Optimasi Derajat Keasaman (pH)}

Salah satu faktor yang menentukan reaksi penandaan yaitu derajat keasaman $(\mathrm{pH})$. Setiap reaksi mempunyai $\mathrm{pH}$ optimum yang berbeda-beda. Hasil optimasi $\mathrm{pH}$ penandaan ${ }^{131}$ I-Apigenin ditunjukkan pada Gambar 6.

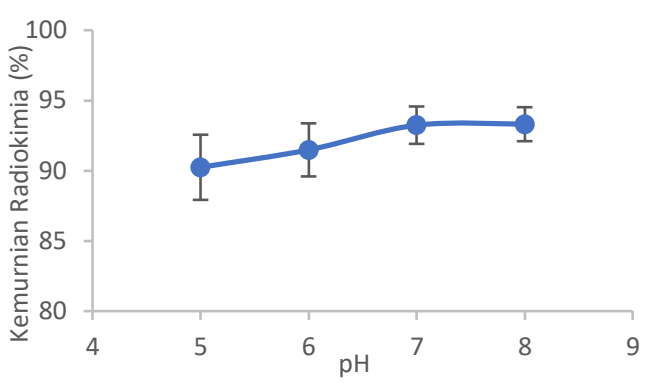

Gambar 6. Pengaruh $\mathrm{pH}$ terhadap penandaan ${ }^{131}$ |Apigenin

Pada Gambar 6, terlihat bahwa pH penandaan berkisar antara $\mathrm{pH} 7$ dan 8 yang memberikan kemurnian radiokimia penandaan secara berturut-turut sebesar $93,24 \%$ dan $93,31 \%$. Selain itu pada Gambar 6 terdapat kecenderungan yang linier antara $\mathrm{pH}$ dan kemurnian radiokimia, semakin tinggi $\mathrm{pH}$ maka semakin tinggi kemurnian radiokimia yang diperoleh. Reaksi radioiodinasi terjadi ketika ion $\mathrm{I}^{-}$dari $\mathrm{Na}^{131}$ I teroksidasi oleh kloramin- $\mathrm{T}$ menjadi ion $\mathrm{I}^{+}$ dalam bentuk iodium monoklorida (ICI) (21) atau asam hipoiodo (HOI) yang akan mensubtitusi ion $\mathrm{H}^{+}$pada senyawa apigenin melalui reaksi substitusi elektrofilik (23). Namun, karena kemurnian radiokimia yang diperoleh pada $\mathrm{pH} 7$ dan 8 tidak jauh berbeda, maka dipilih $\mathrm{pH} 7$ agar mendekati $\mathrm{pH}$ darah.

\section{Optimasi Jumlah $\mathrm{Na}^{131}$ I}

Reaksi penandaan juga ditentukan oleh jumlah $\mathrm{Na}^{131}$ I yang digunakan, maka perlu dilakukan optimasi jumlah $\mathrm{Na}^{131}$ I yang ditunjukkan pada Gambar 7. 


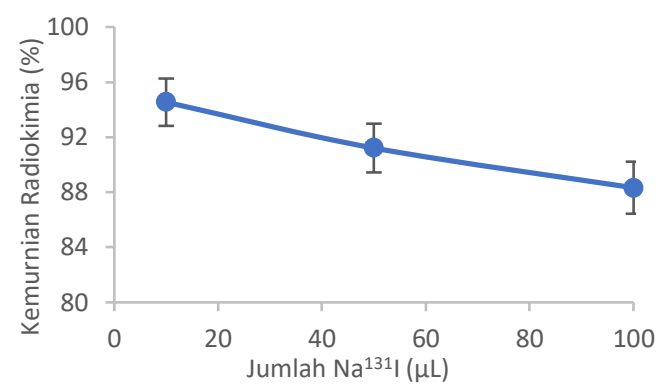

Gambar 7. Pengaruh jumlah $\mathrm{Na}^{131}$ | terhadap kemurnian radiokimia penandaan ${ }^{131} \mathrm{I}$-Apigenin

Pada Gambar 7, terlihat bahwa semakin banyak jumlah $\mathrm{Na}^{131} \mathrm{I}$, maka semakin rendah kemurnian radiokimia ${ }^{131}$ IApigenin. Penurunan kemurnian radiokimia tersebut dapat diakibatkan oleh adanya pengotor dalam bentuk $\mathrm{Na}^{131}$ I yang tidak terionisasi atau ion $\mathrm{I}^{-}$yang belum teroksidasi oleh kloramin-T. Jumlah pengotor $\mathrm{Na}^{131}$ I maupun ion I' perlu diperhatikan karena dapat menimbulkan kesalahan interpretasi data. Sehingga pada penelitian ini volume $\mathrm{Na}^{131} \mathrm{I}$ yang digunakan sebanyak $10 \mu \mathrm{L}$. Penggunaan $\mathrm{Na}^{131}$ | di bawah $10 \mu \mathrm{L}$ atau radioaktivitas yang terlalu rendah dapat mempersulit proses pengujian kemurnian radiokimia, karena radioaktivitas yang terdeteksi oleh alat radio-TLC scanner sangat kecil sehingga sulit membandingkan antara puncak radioaktivitas ${ }^{131} \mathrm{I}$-Apigenin dan pengotor, serta mengakibatkan pengujian kemurnian radiokimia menjadi tidak akurat.

\section{Optimasi Jumlah Apigenin}

Setiap reaksi mempunyai waktu optimum yang berbeda, begitu pun reaksi penandaan ${ }^{131}$ I-Apigenin. Waktu reaksi yang dimaksud adalah waktu yang dibutuhkan untuk oksidasi $\mathrm{Na}^{131}$ I dan reaksi substitusi elektrofilik hingga reaksi dihentikan dengan penambahan natrium metabisulfit. Agar diperoleh waktu optimum, maka dilakukan variasi waktu reaksi mulai dari $5,10,20$, dan 30 menit. Hasil optimasi waktu reaksi ditunjukkan pada Gambar 8.

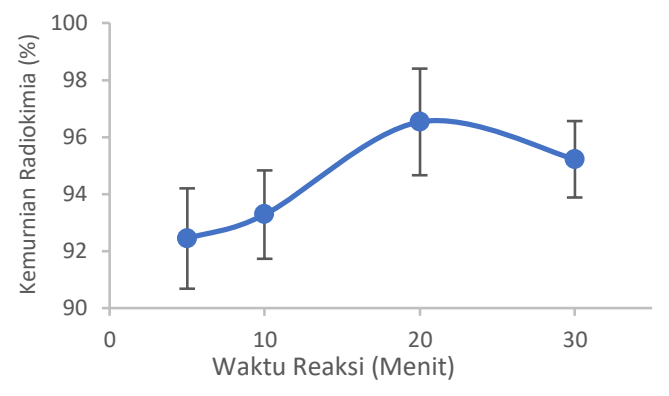

Gambar 8. Pengaruh waktu reaksi terhadap kemurnian radiokimia hasil penandaan ${ }^{131}$ IApigenin

Pada Gambar 8, ditunjukkan waktu reaksi optimum yang relatif singkat yaitu pada waktu 20 menit. Waktu reaksi merupakan waktu yang dibutuhkan kloramin$\mathrm{T}$ untuk mengoksidasi ion $\mathrm{I}^{-}$menjadi ion $\mathrm{I}^{+}$, kemudian ion $\mathrm{I}^{+}$mensubstitusi ion $\mathrm{H}^{+}$yang terdapat pada apigenin. Waktu reaksi perlu dibatasi untuk menghindari kondisi oksidasi yang belebih. Karena kloramin-T merupakan senyawa yang sangat reaktif, maka terdapat kemungkinan kloramin-T akan mengoksidasi senyawa apigenin, sehingga reaksi oksidasi oleh kloramin-T perlu dihentikan melalui penambahan natrium metabisulfit (24).

\section{KESIMPULAN}

Dari hasil optimasi berbagai parameter penandaan diperoleh senyawa ${ }^{131} \mathrm{I}$-Apigenin dengan kemurnian radiokimia $96,53 \pm 1,87 \%$. Formula dan kondisi penandaan yang diperoleh antara lain: $1 \mathrm{mg}$ apigenin, $250 \mu \mathrm{g}$ kloramin-T, $100 \mu \mathrm{g}$ natrium metabisulfit, $\mathrm{pH} 7$, 
jumlah $\mathrm{Na}^{131}$ I $10 \mu \mathrm{L}(10 \mu \mathrm{Ci})$, serta waktu reaksi selama 20 menit pada suhu kamar. Dari hasil tersebut, senyawa bertanda ${ }^{131} \mathrm{I}$ Apigenin dapat dilanjutkan ke tahap studi fisikokimia selanjutnya (uji lipofilisitas, uji ikatan dengan protein plasma, uji stabilitas plasmatik, dan uji stabilitas penyimpanan) serta studi praklinis, sehingga dapat diperoleh bioaktivitas dari ${ }^{131}$ I-Apigenin.

\section{UCAPAN TERIMAKASIH}

Penulis mengucapkan terima kasih kepada PSTNT BATAN atas dukungan finansial melalui DIPA 2019 untuk penelitian ini.

\section{DAFTAR PUSTAKA}

1. Bray F, Ferlay J, Soerjomataram I, Siegel RL, Torre LA, Jemal A. Global cancer statistics 2018: GLOBOCAN estimates of incidence and mortality worldwide for 36 cancers in 185 countries. CA Cancer J Clin. 2018;68(6):394-424.

2. Singh S, Sharma B, Kanwar SS, Kumar A. Lead phytochemicals for anticancer drug development. Front Plant Sci. 2016;7(November 2016):1-13.

3. Zhou Y, Zheng J, Li Y, Xu DP, Li S, Chen YM, et al. Natural polyphenols for prevention and treatment of cancer. Nutrients. 2016;8(8).

4. Madunić J, Madunić IV, Gajski G, Popić J, Garaj-Vrhovac V. Apigenin: A dietary flavonoid with diverse anticancer properties. Cancer Lett. 2018;413:1122.

5. Tang D, Chen K, Huang L, Li J.
Pharmacokinetic properties and drug interactions of apigenin, a natural flavone. Expert Opin Drug Metab Toxicol. 2017;13(3):323-30.

6. Sung B, Chung HY, Kim ND. Role of Apigenin in Cancer Prevention via the Induction of Apoptosis and Autophagy. J Cancer Prev. 2016;21(4):216-26.

7. Perrott KM, Wiley CD, Desprez PY, Campisi J. Apigenin suppresses the senescence-associated secretory phenotype and paracrine effects on breast cancer cells. GeroScience. 2017;39(2):161-73.

8. Shukla S, Gupta S. Apigenin: A promising molecule for cancer prevention. Pharm Res. 2010;27(6):962-78.

9. Cvetanović A, Švarc-Gajić J, Gašić U, Tešić Ž, Zengin G, Zeković Z, et al. Isolation of apigenin from subcritical water extracts: Optimization of the process. J Supercrit Fluids. 2017;120:32-42.

10. Salehi B, Venditti A, Sharifi-Rad M, Kręgiel D, Sharifi-Rad J, Durazzo A, et al. The therapeutic potential of Apigenin. Int J Mol Sci. 2019;20(6).

11. Ali F, Rahul, Naz F, Jyoti $S$, Siddique $\mathrm{YH}$. Health functionality of apigenin: A review. Int J Food Prop. 2017;20(6):1197-238.

12. Wang N, Yi WJ, Tan L, Zhang JH, Xu J, Chen $Y$, et al. Apigenin attenuates streptozotocin-induced pancreatic $\beta$ cell damage by its protective effects on cellular antioxidant defense. Vitr Cell Dev Biol - Anim. 2017;53(6):554-63. 
13. Khole S, A Panat N, Suryawanshi P, Chatterjee S, Devasagayam T, Ghaskadbi S. Comprehensive Assessment of Antioxidant Activities of Apigenin Isomers: Vitexin and Isovitexin. Free Radicals Antioxidants. 2016;6(2):155-66.

14. Mirzoeva S, Tong X, Bridgeman BB, Plebanek MP, Volpert O V. Apigenin Inhibits UVB-Induced Skin Carcinogenesis: The Role of Thrombospondin-1 as an AntiInflammatory Factor. Neoplasia (United States). 2018;20(9):930-42.

15. Patil $R H$, Babu RL, Naveen Kumar $M$, Kiran Kumar KM, Hegde SM, Nagesh $\mathrm{R}$, et al. Anti-Inflammatory Effect of Apigenin on LPS-Induced ProInflammatory Mediators and AP-1 Factors in Human Lung Epithelial Cells. Inflammation. 2016;39(1):138-47.

16. Seyitoglu B, Yurt Lambrecht F, Durkan $\mathrm{K}$. Labeling of apigenin with $131 \mathrm{I}$ and bioactivity of 131/-apigenin in male and female rats. J Radioanal Nucl Chem. 2009;279(3):867-73.

17. Woltanski KP, Besch W, Keilacker H, Ziegler M, Kohnert KD. Radioiodination of Peptide Hormones and Immunoglobuline Preparations: Comparison of the Chloramine $\mathrm{T}$ and lodogen Method. Exp Clin Endocrinol Diabetes. 1990;95(1):39-46.

18. Choi MH, Rho JK, Kang JA, Shim HE, Nam YR, Yoon S, et al. Efficient radiolabeling of rutin with $125 \mathrm{I}$ and biodistribution study of radiolabeled rutin. J Radioanal Nucl Chem.
2016;308(2):477-83.

19. Hanafiah A, Widyasari EM, Oekar NK, Teknologi P, Bahan N. Pembuatan, pemurnian dan stabilitas. J Sains dan Teknol Nukl Indones. 2011;XII(2):7584.

20. Sanad MH, Challan SB.

Radioiodination and biological evaluation of rabeprazole as a peptic ulcer localization radiotracer. Radiochemistry. 2017;59(3):307-12.

21. Behr TM, Gotthardt M, Becker W, Béhé M. Radioiodination of monoclonal antibodies, proteins and peptides for diagnosis and therapy. Nuklearmedizin. 2002;41(02):71-9.

22. Saha GB. Fundamentals of Nuclear Pharmacy. 6th ed. New York: Springer; 2010.

23. Eka Sriyani M, Ayu Utami D, Dwike Susilo M, Maria Widyasari E, Marzuki $M$, Juwita Sugiharti R, et al. Synthesis of 131 l labeled quercetin through oxidation method using chloramine-T for cancer radiopharmaceuticals. Indones J Chem. 2019;19(4):841-8.

24. Janssens $Y$, Verbeke F, Debunne N, Wynendaele E, Peremans K, De Spiegeleer B. Analysis of iodinated quorum sensing peptides by LCUV/ESI ion trap mass spectrometry. J Pharm Anal. 2018;8(1):69-74. 
Jurnal Sains dan Teknologi Nuklir Indonesia

Indonesian Journal of Nuclear Science and Technology

ISSN $1411-3481$

Vol. 21, No.1, Februari 2020: 49-60

- Blank Page - 